\title{
The Philosophical Category of "Risk"
}

\section{Maso S*}

Department of Philosophy and Cultural Heritage, Ca' Foscari University, Italy

\section{Conceptual Paper}

Volume 1 Issue 1

Received Date: July 31, 2018

*Corresponding author: Stefano Maso, Department of Philosophy and Cultural Heritage, Ca' Foscari University, Venice, Italy, Email: maso@unive.it
Published Date: August 15, 2018

DOI: $10.23880 /$ phij-16000102

\begin{abstract}
Although not all scholars are willing to recognize it, "risk" is a real philosophical category. However, it is necessary to distinguish risk from danger. The danger is something defined and arranged by reason. So we can face it and we can defend ourselves from it. The risk is in the background: it remains beyond rational awareness. The analysis of the etymology of risk leads us to the Arab-Byzantine era. The Greek language instead possessed the word kindynos, in which the thing or the action you want to experiment is probably hidden. For this reason, risk and courage are frequently combined. Probably, we can catch the essence of Western civilization in the game between risk and reason. The foundation of this is in Greek culture: from Homer to Plato and Aristotle. Greek tragedy is the place where "risk" appears conjugated to destiny.
\end{abstract}

Keywords: Risk; Danger; Courage; Phronesis; Kindness; Destiny; Plato; Aristotle; Greek tragedy

\section{Risk or Danger?}

Many philosophical concepts today are used in a blurry way because they are employed in the common language without paying particular attention to the necessary nuances. Their application becomes superficial and therefore inadequate. In summary, comparing the language and the meaning of words is an important task of philosophy: the philosopher has to analyze those words that convey basic concepts, in particular those that may imply decisions and actions.

The concept of "risk" is central to the world and to modern society. Already in 1986 Ulrich Beck, in the book Risikogesellschaft: Auf dem Weg in eine andere Moderne, began to investigate its traits, starting from assumptions of a primarily sociological / anthropological nature. However, risk is a concept that seems to have taken on a sufficiently precise definition only in the late period ${ }^{1}$ and which even today does not appear so unequivocally connoted as to be elevated to an authentic philosophical category [1].

As regards the etymological side, according to the linguistic lexical attestations, we must refer to the ArabByzantine environment. It is indeed in the phase of the Arab expansion in the Mediterranean that the term rizq (Arabic) and rizikòn (Greek-Byzantine) is used to indicate the silver pay of the mercenary soldier. He is in fact the

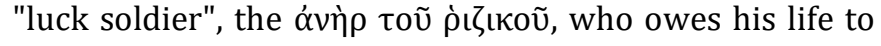

${ }^{1}$ Luhmann N (1991) Risk: A Sociological Theory (Communication and Social Order). De Gruyter, Berlin-New York, believes that the modern meaning of "risk" has been affirmed, in a clear way, only in the medieval period. 


\section{Philosophy International Journal}

"fate" and "destiny" (* to riziko) ${ }^{2}$ and which constitutes the means often used by "fate" and "destiny" to decide the life of other men [2-6]. The Neo-Latin word risicum descends directly and ends up translated into all modern European languages, meaning, on the one hand, that which opposes security; on the other, the act of courage or boasting of those who deal with something of which they don't know the limits or characteristics. On the other hand, it is probable that the etymology that refers to the Latin resecare should be rejected, which would introduce the subjective perspective into the concept of "risk", in which there is someone who "cuts", who "decides" something, causing irreversible and unpredictable consequences, but of which he still bears the responsibility.

Danger, risk, adventure, and hazard: today all are words and concepts that contribute to define the very meaning of "risk". One wonders, however, about the convenience of isolating them from one another, since the application of the term "risk," to the most diverse spheres of modern specialist sciences (from economics to the medicine or assurance or mathematics) now highlights one or the other meaning. In this way the value of the term with respect to its original comprehension would also be significantly rejected. However, the frequency of expressions such as "being in danger of life" and "running the risk of dying" appears interesting: synonymic use seems to prevail, since the exact situation seems to have been intended. Furthermore the use of the "risk and danger" hendiadys ends up, on the one hand, to confirm the ancient complexity and comprehension of the term "risk"; on the other, to justify the tendency, common in modern languages, to confuse the original distinct valences of the two distinct words.

Today it seems that "risk" and "danger" coincide. However, I believe that some polarity between the various meanings of "risk" and "danger" can still be highlighted.

The Latin periculum is related to the verb periclitor, which refers to the idea of "trying something", of "grappling" and, at the same time, of "running a danger".

${ }^{2}$ Despite some perplexities on the part of linguists, this would seem to be the most probable reconstruction of the history of the word. Seead loc: Ernout A. - Meillet A. $1979^{4}$ Dictionnaire Etymologique de la langue latine. Histoire des mots. Klincksieck, Paris; Chantraine P. (1983) Dictionnaire étymologique de la langue grecque. Histoire des mots. Klincksieck, Paris (or. ed. 1968); Cortelazzo M. - Zolli P. (1979-1985) Dizionario etimologico della lingua italiana. Zanichelli, Bologna; De Vaan M. (2008) Etymological Dictionary of Latin and the Other Italic Languages. Brill, Leiden-Boston; Beekes R. \& Beek L. van (2010) Etymological Dictionary of Greek, voll. 1-2. Leiden-Boston, Brill.
In the background, there is the Greek word that indicates

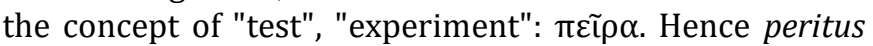
will be the one who has had some experience ( $\dot{\varepsilon} \mu \pi \varepsilon \rho^{\prime}(\alpha)$, who took a certain risk in doing it and then became "expert".

Along the way, Luhmann attempts a first disambiguation between risk and danger, perceiving a sort of asymmetry between the two concepts, so that "risk" would indicate a concrete case in which the ability to "decide" would come into play, where we would simply be "exposed" to danger.

Unlike Luhmann, I instead propose ${ }^{3}$ to distinguish between risk and danger with reference to their different relationship to the possibility of insisting on something "determined" [7]. Thus, the "risk" refers to an extremely broader concept: to something so "indeterminate" that escapes the control of rationality; the "danger", on the other hand, is nothing other than the single form in which the "risk" is transformed, in a rationally circumscribed way.

In line with this proposal, we can also disambiguate risk and danger with respect to the way in which they present themselves and/or are perceived by the human subject. Let us take into consideration the case of a DANGEROUS PATH and a HIGH-RISK BEHAVIOUR.

A "dangerous path" implies that the objective insecurity (i) of an $\mathrm{X}$ route $(\mathrm{T})$ is made clear by the decision (d) of acting (a) by a certain subject $\mathrm{S}$.

However the acknowledgement of the T insecurity (= Ti) is not possible without an intervention (a) put into effect (d) by S. Practically Ti $\subset S d a^{t}$, where the exponent refers to the moment when it takes place $d+a$ on the part of S. The dangerousness may always be there, but the subject is at risk (faces DANGER and shows its existence) only thanks to a temporary decision.

On the contrary, a "high-risk behavior" B (behavior in which the subject plays with instability and puts its own security at risk: $\mathrm{B}=\mathrm{da}+\mathrm{i}$ ) does not expect any specific intervention which, in a given time, allows the outbreak of potential dangerousness. It already coincides with dangerousness because $\mathrm{B} \subset \mathrm{S}$ without any further time variable goes beyond the fact of belonging. It is dangerousness in act.

What is dangerous (in the example: Ti) in theory might not reveal itself because an intervention of $\mathrm{S}$ is not certain

${ }^{3}$ See Maso S (2006) Fondements philosophiques du risque. L'Harmattan, Paris, pp.17-37. 


\section{Philosophy International Journal}

and could never be put into effect. But what is risky (in the example: B) immediately reflects the dangerous side of that way of acting that can belong to S. This without further determinations that are not originated by the fact of being $\mathrm{S}$ and therefore necessarily of being able to decide acting (in fact $S \supset B$ by definition: a subject is not real if he does not have the possibility of deciding to act and therefore to deal with instability). Furthermore: if it is possible that something dangerous does not appear this way (this happens when $\mathrm{S}$ does not grasp distinctive features of what stands in front of him: Ti $\not \subset \mathrm{Sda}^{\mathrm{t}}$, or $\mathrm{T} \subset$ $\left.S d a^{t}\right)$, is unimaginable that what is risky is not warned as dangerous too. Since in fact $\mathrm{B} \supset \mathrm{T}$ (where $\mathrm{T}$ does not necessarily appear in his instability Ti), it is B (which by definition is da+i) that has the responsibility of leading instability. In short, it will be the subject who risks (in fact $\mathrm{S} \supset \mathrm{B})$ who must agree whether the danger of the contents (a) of his own decisions (d) are detectable or not. In a sense we can therefore consider irrelevant the $T$ instability (Ti), given that there is the original one of $\mathrm{B}$ that involves inevitably also T. In fact, many gestures of our daily lives are not dangerous, such as walking, caressing someone, making breakfast, writing a text, but they too can become dangerous if the emphasis move in the direction of the subject. For reasons all to be clarified but however belonging to its essence, the subject may deem dangerous even walking, caressing a person, making breakfast, writing a text(i.e. the instability may thus be noticed and therefore the danger of the single gesture).

This approach allows us to fully recover the role of modern scientific reason. The reason would assert itself precisely because of its capacity of rationalizing the "risk", that is, to arrive at a vision of reality from which the presence of the authentic "risk" (i.e. the dramatic experience of what is not rational and whose power can even be perceived as destructive) has been removed.

According to this perspective, in the face of man and human society we would find only "dangers": it could also be innumerable or very serious dangers, but in any case we would always have to deal with a definite and determined series of situations. Faced with these, man's rationality and scientific-technological capacity are able to produce "remedies" and to avoid (or limit) damage. It seems clear, in this sense, as the attempts to calculate the probability (in mathematics or in statistics), the precautionary principle (in sociological and psychological domains), the prevention principle (in the field of medicine or the environment), and the insurance strategies (in economics or finance) consistently converge in one direction.
But we must be careful: we are always dealing with rational responses elaborated in such a way as to remedy what the same reasoning has succeeded in determining: that is, to remedy the dangers that reason has at first identified, and for which it has then developed the appropriate remedy. What is in the background, i.e. behind this certain series of certain dangers, is the real risk, and is exactly that which the civilization of technology so desperately wants to escape.

\section{Humana conditio}

However, as the "risk" - not the "danger"- is perceivable in its essence remains the decisive question for the man of today. It seems in fact that man today is destined to chase the innumerable series of dangers; he is doing it with great skill and, at the same time, with great satisfaction, demonstrating to himself the strength of his scientific rationality and the power of the technology he possesses. This really seems to be the humana conditio in which progress is expressed and the future of the universe is planned.

Optimistically, in spite of himself, Ulrich Beck has recently tried to build a model of global society where the "risk" of failure is present. In other words, he has attempted to outline and explain the interdependence framework to which we report the political choices of all nations, the ecological decisions, and the cyclical economic and social crises. He even proposed a "Critical Theory of the Global Risk Society". In it, he gives great space to the questions of "responsibility", of political selfcriticism, of the dialectic between progress and conservation in the institutions of modernity. In conclusion, he presented a refined analysis of the risk category that would appear to be the updated comprehensive starting point to be used today to find a remedy for the situation in which humanity finds itself.

I observe that, once again, we are dealing with the result - a very commendable result - of the strategic reconfiguration of the "risk" to "danger": i.e. the reduction of a condition of understanding and therefore of governability of what (and this is the true "risk") remains in reality "indeterminable".

To be sure, we must acknowledge that (a) this is the fragile contemporary conditio humana, and that (b) conditio humana means the existential condition of the human subject. This subject, driven by his nature to measure himself with what he ignores, projects himself always beyond the limit of what, which until now has been able to determine and produce, always hovering between success and failure. 


\section{Philosophy International Journal}

What is important now to consider is that chance (or fortune or hazard) has not established this status; all that happens follows the progressive imposition, in the Western world, of a very precise form of rationality: of a logos that could transform itself into an epistêmê and a technê $\hat{e}^{4}$ to counter and defeat any other mode of knowledge and action in the world $5[8,9]$.

\section{Facing the Risk}

If now we want to try to understand what the modern concept of "risk" refers to and therefore what it can really imply we need to go back to Greek philosophy and to the way it relate to "what is not determined" and therefore "is unpredictable", "elusive", "unmanageable".

First, let us look at the word that the Greeks used to

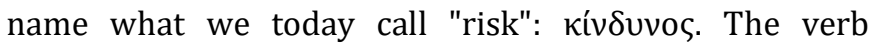

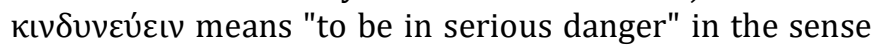
of "being in front of a risk" that presents itself in its concreteness and inevitability ${ }^{6}[3,6,10]$.

It is possible that the first meaning refers to the "test of fire", in front of which it is necessary to show one's physical or moral strength from which justice is promoted.

${ }^{4}$ On the subject of technê - a central topic in the twentieth-century thought on the history of Western man - I refer first of all to the writings of Martin Heidegger, starting from the essay The Age of the World Image, in Heidegger M. (1952) Holzwege. Klostermann, Frankfurt a.M, which dates back to 1938. From a sociological perspective, the research of Arnold Gehlen remains decisive: among other things, he highlighted the theme of automation in the industrial field: cf. Gehlen A. (2004) Die Seele im technischen Zeitalter. Sozialpsychologische Probleme in der industriellen Gesellschaft (1957-1971). In Gesamtausgabe, von K.S. Rehberg, Klostermann, Frankfurt a.M. 2004, VI, pp. 5-23.

${ }^{5}$ Technê and epistêmê are strongly connected. To the traditional and

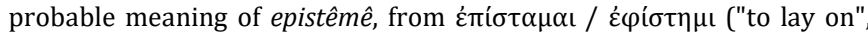
"to be placed above": in reference to knowledge or to who owns it), it should be added that of technê, whose Indo-European root *tek is also at the base of $\tau \dot{\kappa} \kappa \tau \omega \nu$ (the "craftsman": one who possesses a specific competence derived from his experience). With regard to the characteristics of epistemic knowledge, Aristotle (Sophistical refutations, chapter 34) draws it in reference to the deductive art, emphasizing however how this knowledge is based on the ability and possibility of finding the "principle". So, the principle is what it is more important than

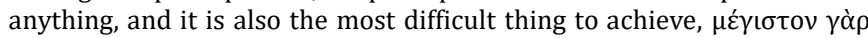

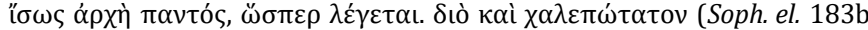
22-23). But once the "principle" is achieved, everything follows.

${ }^{6}$ The first meanings, listed in the Liddell-Scott Dictionary, are: "to be daring, run risk, make a venture, take a risk, to be in dire peril, to be in danger". However, the etymology remains controversial and does not seem to have given reliable fruits as regards the Indo-European derivation, cf. Chantraine 1983,cit., pp. 532-33; Beekes-Beek 2010, cit., pp. 699-700. A pre-Greek or Anatolian origin seems more likely, as Semerano G. (1974) Le origini della cultura europea, vol. II, 1: Dizionario Della lingua greca. Olschki. Firenze, p. 140, suggests.
According to Giovanni Semerano (an Italian glottologist, who theorized the centrality of the Akkadian / Semitic languages), the $\boldsymbol{\kappa} \boldsymbol{} \boldsymbol{v}$ component refers to the Akkadian kīnu (legitimate), kintu<kittu (justice). But see also the Latin cinis (in Greek: kóvıs), the ashes of fire, in connection with the Akkadian kinūnum and other Mesopotamian languages and the Arabic kānūn: the furnace, the brazier where the fire and the ash are found. This is followed by the component $-\boldsymbol{\delta} \boldsymbol{v} \boldsymbol{v}-$, which, in Akkadian dūnu, dunnu means "force", "violence".

We see that this constellation of meanings allows us to reconstruct a situation comparable to that of Ulysses, the

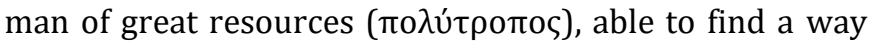
out on any occasion, capable to escape even from the fire (i.e. from extreme danger), by virtue of his faculty to "think" for the best.

The hero Diomedes, in the event of being in danger, would prefer to be in the company of Ulysses:

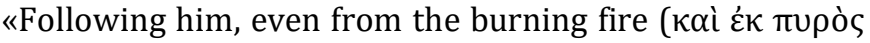

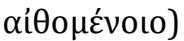

we both would escape, because he knows how to think for the best»,

Iliad 10. 246-7.

The Greek man is always present to the dangers of the battle, where he risks death, and the danger of the fire that sets the city on fire and causes destruction. Then there is the danger of the sea and of navigation ${ }^{7}$ [7]. The Greek man knows that he must be tested continuously and that only in this way can he become an expert and overcome obstacles. It is not possible to imagine an "expert" who has never been put to the test, who has never been in a dangerous situation and who, eventually, has not activated an action strategy and has not taken any personal "decision".

Similarly, we can imagine the situation of the man who, faced with the law and the judge, must answer for a crime and runs the danger of death: Socrates knows this well, defending himself in front of the Athenian court:

«And what, Socrates, will you tell me, do not you regret having led a kind of life that, today, puts you in

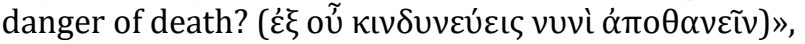
Plat., Apol. 28b.

Phronesis, the practical intelligence that does not limit itself to speculation but instead produces decisions and consequent actions, is what saves man from kindynos.

${ }^{7}$ See Maso (2006) cit., pp. 21-26. 


\section{Philosophy International Journal}

Ulysses was in possession of phronesis, as well as Socrates; phronesis becomes the reference to which the wise man of Aristotle aspires. The work of Aristotle, above all the ethical work, is dominated by the presence of phronesis, and, consequently, the very possibility that the kind of wise man (to whom Aristotle himself thinks ${ }^{8}$ ) [11] may encounter danger is greatly reduced. Thus, we read in the third book of Nicomachean Ethics:

«The great-souled man does not run into danger for

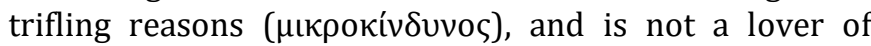

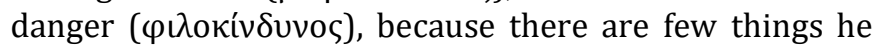
values; but he will face danger in a great cause

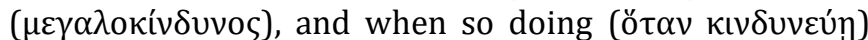
will be ready to sacrifice his life, since he holds that life is not worth having at every price».

Aristot., EN 1124b 6-9 (transl. H. Rackham).

This is a significant passage because it explains that the wise man is essentially a measured man: he is not a lover of danger or of challenge; even if at times (i.e. when he judges that it is worth it) he knows how to put his life on the line. But it is important to note that this is one of the rare passages of the entire Aristotelian work in which the subject of danger is directly addressed ${ }^{9}$. In order to do so, Aristotle had previously (chapters 9-12, SusemihlApelt) put on theme the "courage", $\grave{\eta} \alpha v \delta \rho \varepsilon i \alpha$, and the

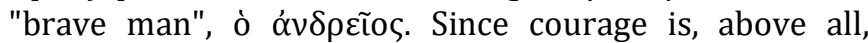
defined as a "mediety" between fear and temerity

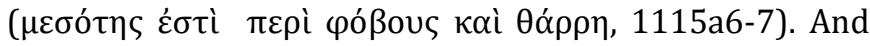
since, courage can manifest itself better in the topical circumstances of danger (death and war are also evoked in addition to illness and navigation at sea), Aristotle considers precisely kindynos the best way to test the man who declares himself courageous, and distinguishes himself not only from the base (ò $\delta \varepsilon \lambda \lambda_{\text {s }}$ ), but also from the rash man (ò $\theta \rho \alpha \sigma u ́ \varsigma){ }^{10}$ and the impulsive man (oi

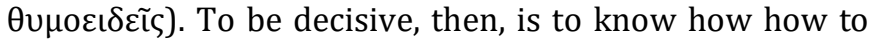
deal with dangers correctly and swiftly ${ }^{11}$.

If someone observes a man who often deals with sudden dangers more than is typically expected of a

${ }^{8}$ On practical wisdom in Aristotle see Natali C. (2001) The Wisdom of Aristotle. State University of New York Press, Albany, pp. 39-61.

${ }^{9}$ They are altogether less than 100 passages; one third of them belongs to the Eudemian Ethics (15) and to the Nicomachean Ethics (17).

${ }^{10}$ Aristotle, E.N. 1116a 7-8, defines the rash man in this way: «The rash, moreover, are impetuous, and though eager before the danger comes

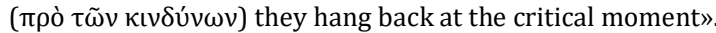

${ }^{11}$ E.N. 1115b 18-19: «The courageous man then is he that endures or fears the right things and for the right purpose and in the right manner and at the right time, and who shows confidence in a similar way. For the courageous man feels and acts as the circumstances merit, and as principle may dictate ( $\dot{\omega} \varsigma \hat{\alpha} v$ ò $\lambda o ́ \gamma o \varsigma) »$. greatly courageous man, it could be replied that this depends more on the disposition and character of this man (that is, by an accidental circumstance) than his conscious preparation ${ }^{12}$. In short, for Aristotle the comparison between kindynos and phronesis resolves completely in favor of the second: and so because the strength of phronesis is such that it greatly reduces the possibility that man, courageous or not, comes to be in dangerous situations.

The dangerous actions, in practice, tend not to exist as such because they can always be framed in a rational perspective, able to weaken their disruptive, and at the same time worrying power.

More than in Aristotle, the presence of kindynos is, so to speak, constant in Plato ${ }^{13}$ [12]. Unlike what happens with Aristotle, to plunge into the dangers and put at risk his life and his integrity is, for Plato, decisive. Plato thinks that man can experience his value, his technical skills and his own wisdom only in conditions of risk ${ }^{14}$. It is not by

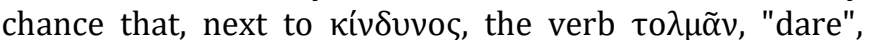
occurs repeatedly ${ }^{15}$ : this verb evokes the famous cry of Prometheus, the hero nailed for punishment to the rock by Zeus:

${ }^{12}$ E.N. 1117a 17-22: «Hence it is thought a sign of still greater courage to

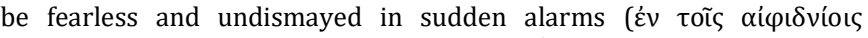

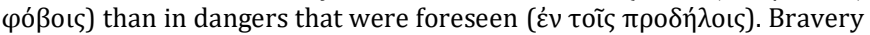
in unforeseen danger springs more from character (ámò $\varepsilon \xi \xi \omega \varsigma$ ), as there is less time for preparation ( $\varepsilon \kappa \pi \alpha \rho \alpha \sigma \kappa \varepsilon \cup \tilde{\Upsilon} \varsigma$ ); one might resolve to face a danger one can foresee, from calculation and on principle, but only a fixed disposition of courage will enable one to face sudden peril».

${ }^{13}$ See Maso S. (2012) Val la pena rischiare? Qualche osservazione sulla categoria filosofica di «rischio» in Platone. "La Ricerca Folklorica" 66: 8595.

${ }^{14} \mathrm{As}$ for the educational function of risk and of testing oneself, it is sufficient to remember that this is the central theme of the VII book of the Laws, which supports the importance of being educated to "risk". This applies to everyone, including women. It would be a great misfortune, for the city and its constitution, that women were considered by nature inferior and, therefore, they were so shamefully educated "that they were not even willing to die and to take any risks

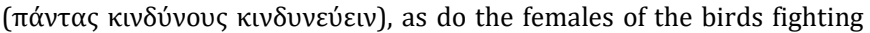
for their children against the strongest among the beasts"(Leg. 814B). Plato is convinced that in any case we must assume the task and the risk

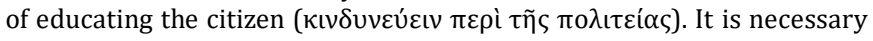
to bet on the law: and if at first sight such a decision might seem analogous to that on which the dice are thrown, in reality, since we belong to a civil society, we cannot avoid such an educational

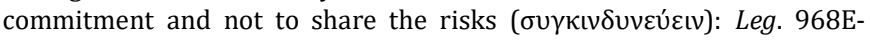
969A.

15Plat., Apol. 39A; Theaet. 196D; Leg. 835C, 976B. In Menex. 240E, Aspasia, the noble friend of Socrates and Plato, in his epitaph states that

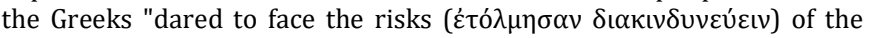
subsequent battles for their own salvation" only because they remembered the memory of Marathon. 


\section{Philosophy International Journal}

«Nobody opposed Zeus, outside of me;

I was the one who dared ( $\gamma^{\prime} \gamma \dot{\omega} \delta^{\prime}$ ò $\tau o \lambda \mu \tilde{\eta} \varsigma$ ) to do it, and freed the mortals

from ending up dispersed in Hades.

That is why these sufferings crook me:

painful to endure, pitiful to see»,

Aesch., Prom. 235-238.

As Aeschylus points out, Prometheus assumed his destiny completely, and decided to share with mortals a gift that belonged to the gods. He sought, inside the reed, the secret spark of fire, which is the master of every

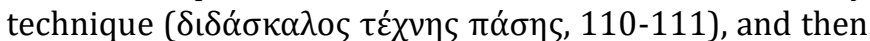
brought it to men. Prometheus was not the only one to commit him; other heroes or deities have "dared". For example, Ocean, which now consoles Prometheus. But Ocean was lucky: no one blames him for anything. He ran

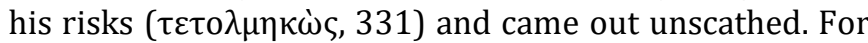
Prometheus, on the contrary, everything is different: to him men owe practically everything they know today:

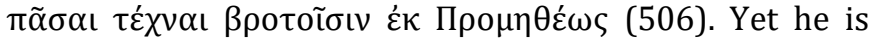
serving for his daring, at a time when - as Aeschylus recognizes - the technique is still "infinitely weaker than

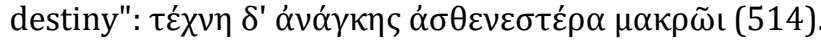

Aeschylus is sure that man has a destiny: that of "being tested". He explicitly states it in The Libation Bearers, when he urges the oracle to say that Orestes "must

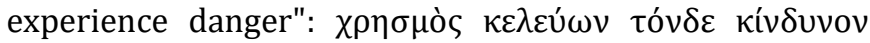
$\pi \varepsilon \rho \tilde{\alpha} \nu(270)$.

I argue that even in Aeschylus and in the Greek tragedy not only has the modern value of "risk" not yet been established, but that with kindynos, despite everything, we still have to deal with a type of risk (or danger) determined ${ }^{16}$ [13]. We have to deal with something that can, and therefore must, be faced with the courage and the audaciousness of our actions and decisions, even if it is clear that destiny, behind it, is governing. Similarly, in Plato man faces the danger because he has been able to recognize, since he is in possession of a rational capacity (logos), and because he presumes to be able to win, since he is in possession of a scientific strategy (technê). Here it is not interesting to analyze this aspect in detail: rather, the focus should be placed where logos and technê intersect, when the man

${ }^{16}$ The tragedy expresses in a determined way the obsessions, the contradictions, the ambiguities and the dangers to which the Greek polis and the social project that supported it are going to meet. What dark faults behind? In this direction, the research of Vernant J.P. \& VidalNaquet P. (1981), Tragedy and myth in ancient Greece, Harvester Brighton (or. ed. 1972), remain fundamental. "decides" that he will use logos and technê (i.e. the modern science). In myth, as it is evident, Prometheus represents precisely this.

But what are the features of this "decision"? Does it appear to be consciously aware or does it contain the maximum "hazard"?

Once again, it is necessary to point out that we are completely far from the concept of the world and the "theory of action" developed by Aristotle. We are not dealing with the motivated and rational "choice" that, for Aristotle, means the ability to decide within different possibilities of which the profile has been studied (this is

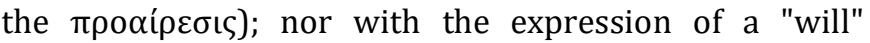
belonging fully to the subject agent and managed on a responsible level ${ }^{17}$ [14-16].

This last point is particularly delicate because it is testimony of the difficulty, in the ancient world, of conceiving the decision and the action in reference to the assumption of responsibility by the thinking and acting subject. The specific word which, in the Greek language of Aristotle, refers in some way to the concept of

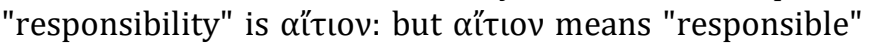
only as a consequence of the fact that, literally, one is "the cause" of something ${ }^{18}$.

\section{Logos, Technê and Risk}

With Aristotle, that is, in the middle of the 4th century $\mathrm{BC}$, the situation is well established: logos and technê are in fact the indispensable tools to face the future and plan the survival of mankind and the world it inhabits.

Previously, up to Plato - that is in practice, until the end of the fifth century BC - the setting was still being structured. Not only were daring and courage estimated: they were judged to be determining factors when making

\footnotetext{
${ }^{17} \mathrm{As}$ for the Aristotelian classification of what is voluntary, involuntary, forced, necessitated, cf. Eth. Eud. 2, 7-9, 1223a21 - 1225a36. The research on the theory of decision and action in the ancient world are today in great development. For Aristotle, in particular, I refer to Destrée P. (2011) Aristotle on Responsibility for One's Character. In M. Pakaluk \& G. Pearson (eds.), Moral Psychology and Human Action in Aristotle. Oxford University Press, Oxford, pp. 278-311. More generally, see Dihle A. (1982) The Theory of Will in Classical Antiquity. University of California Press, Berkeley - Los Angeles - London, pp. 20-67, and Frede M. (2011) A Free Will. Origins of the Notions in Ancient Thought, Berkeley - Los Angeles - London, University of California Press, pp. 19-48. The commonly held thesis is that the modern conception of free will, connected to the free ability of choice, has been affirmed only in late antiquity.
}

${ }^{18}$ The key passage in this regard is the seventh chapter of the book III of Aristotle's Nicomachean Ethics. 
decisions. Science and technology were considered decisive; yet, observes Socrates in dialogue with Laches and with Nicias, how not to take into account that:

«Anyone who agrees to descend into a well, and to dive, and to endure in this or other such action, without being an adept in these things, you would say is more

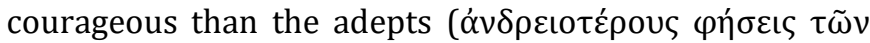
$\tau \alpha \tilde{\tau} \tau \alpha \delta \varepsilon เ v \tilde{\omega} v)$... And you observe, I suppose, Laches, that

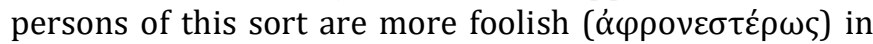

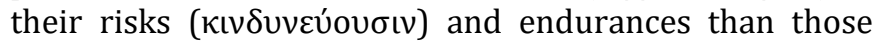

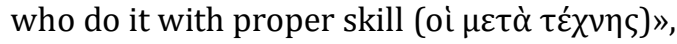
Plat., Laches 193c (trad. W.R.M. Lamb).

In this dialogue, Plato himself questions whether the courage ( $\left.\alpha \dot{\alpha} \delta \rho \varepsilon^{\prime} \alpha\right)$, instead of being pure and simple, is

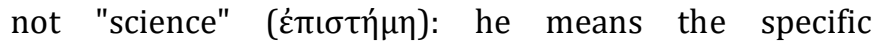
«knowledge of what is to be dreaded or dared ( $\tau \dot{\eta} \nu \tau \tilde{\omega} v$

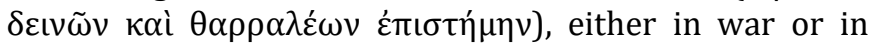
anything else», Lach. 194E. Of course it will be important to distinguish the courage ( $\alpha \dot{\alpha} \delta \rho \varepsilon i ́ \alpha)$ from the lack of fear due to ignorance ( $\left.\alpha \dot{\alpha} \varphi \beta^{\prime} \alpha\right)$, from the temerity ( $\left.\theta \rho \alpha \sigma u ́ \tau \eta\right)$ ),

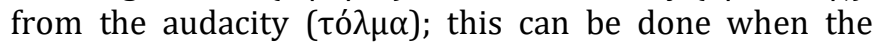
action is combined with the intelligence:

«So you see, the acts that you and most people call courageous ( $\alpha \delta \delta \rho \varepsilon \tilde{i} \alpha)$, I call rash $(\theta \rho \alpha \sigma \varepsilon \dot{c} \alpha)$, and it is the prudent acts ( $\tau \dot{\alpha} \varphi \rho o ́ v \iota \mu \alpha)$ which I speak of that are courageous ( $\alpha \dot{\alpha} \nu \rho \varepsilon \tilde{\varepsilon} \alpha) »$,

Plat., Laches 197B-C.

Yet Socrates, Nicias and Laches do not agree on a definition of courage that is really capable of bringing its characteristics back into scientific knowledge. Courage not only must be "the knowledge of what is to be dreaded or dared", if for "things to dread" we limit ourselves to consider future ills and, for "things to be dared", future assets. As a science, the courage must however refer to the goods and the evils: i.e. in reference to the present as well as to the past and the future (199B-C). Should not this be the same for "courage"?

Perhaps, as a consequence of this, the Platonic Laches is an aporetic dialogue; it does not find a conclusion and instead leaves the interlocutors of past and present the task of answering the main question: is it or is it not absurdity to consider courage a "science"?

If we try to give an answer today, we can perhaps say that it will not be absurd to consider courage as a science only if we can understand its value and its characteristics (which can be associated with the "risk") and envisage it in a double perspective. On the one hand, since it belongs to "what is to be dreaded or dared" (and therefore refers to what is risky to do or decide to do), it demands to be defined and considered in a scientific way, so that specific countermeasures can be taken in different situations. On the other hand, the courage (obviously both to decide and to act) is explicitly presented as the "virtue" of the soul. It is something that evades specific determination. It is precisely because of this that man, at the beginning, began to think and reflect in the moment of action, and therefore to exist as a man. In other words, it was at that moment that the "thought" ventured to abandon its naive original form: at that moment, man had the courage to put the content of his action and its objectives at the center. In practice, the man at that moment intuited and then consequently behaved, knowing that the "risk" should have been evaluated, calculated, and therefore controlled as "danger".

However, behind the decision and action (and the "courage to decide and act") is the absolute opening of risk, the one that in modern times was grasped by Søren Kierkegaard and then by Friedrich Nietzsche. The first theorized the direct implication of "risk" and "possibility" in a perspective that is juxtaposed to the immediate experience of angst. The second probed to the extreme the exciting characteristics of the "risk" in his rising on the nothingness of existence, to grasp the strength of a "risky" and "dancing" life on the chance. Both Kierkegaard and Nietzsche were able to look directly at the "risk", finding themselves, however, to live in an era that had already introjected the character of the values of technology and its power ${ }^{19}$.

Did Plato, and the Greeks before him, manage to look at the "risk" in its maximum openness with similar lucidity and open-mindedness?

\section{Tragedy and the Openness to the "Risk" of Faillure and Madness}

My answer is negative: they were certainly the architects of the advent of an epistêmê able to define and transform the "risk". Yet it has not been canceled but, on

\footnotetext{
${ }^{19}$ See Maso 2006, cit.pp. 77-84, 91-96 and 183-88. Here it is enough to quote $\S 6$ of Thus Spoke Zarathustra, in which to the acrobat smashed to the ground and dying, Zarathustra kneeling says: «You have made your job dangerous (der Gefahr deinen Beruf), and there is nothing in it to disdain. Now you perish for your job ". As you know, this acrobat, shortly before hanging on a rope stretched over the abyss, is the Nietzschean emblem of man: "A dangerous (gefährliches) to go beyond, a dangerous (gefährliches) to be on the way, a dangerous (gefährliches) looking back, a dangerous (gefährliches) to shudder and stop "(§ 4). Any form of rationality in all this would seem to be evocable anyway; the problem is that everything seems rather to "dance on the feet of the chance", auf den Füssen des Zufalls - tanzen (in the chapter Vor SonnenAufgang).
} 
the contrary, it has remained vital in the background: the Greek tragedy supports this theory. Tragedy is the place where the opening to the "risk" of failure and madness is, for man, extreme. There is really no stage action that, in the ritual re-proposition of the myth, does not leave a tragic tension: this tension is removed in the background but is always able to make salvation or perdition possible. For example, we can recall the beginning of Aeschylus' Orestea, the anguished tension on the scene when the lookout finally sees the long-awaited signal: the distant torch light that warns of the conclusion of the Trojan war. It seems that this is the moment to forget (or see removed) the punishment that has affected the palace of Agamemnon and his people for over ten years. The moment of joy should explode, but everything remains pending awaiting the king's arrival. But in a transitory passage the chorus recalls what no one seems to have in mind at the time: what Agamemnon dared to put into action, the act of daring most daringly ( to propitiate the wind favorable to ships, i.e. how he decided to sacrifice his daughter. It seems that a wretched

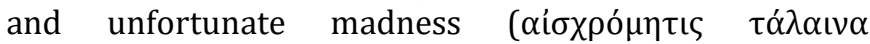
$\pi \alpha \rho \alpha \kappa о \pi \alpha \dot{)}$, a madness that is always the first cause of

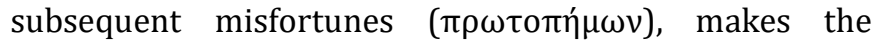

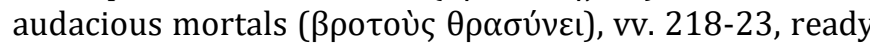
to run towards the most dramatic and dangerous destiny reserved for them. By contrast, Clytemnestra walks happily on the threshold of the palace, throwing out shouts of joy ( $\alpha \omega \omega \lambda{ }^{\prime} \lambda v \xi \alpha, 587$ : it is the first word that she pronounces) waiting to welcome her husband, while she is perfectly aware of the uxoricide she intends to do. Agamemnon, however, is accompanied by Cassandra, the foreign soothsayer now his slave. The chorus still points out that the situation is not resolved and that, on the contrary, everything is at risk: "terror $(\delta \varepsilon \tilde{\mu} \mu \alpha)$ persistently twirls before the heart full of fatal omens", 975-7. Cassandra, when she finally opens her mouth, only throws shouts of horror; then, announces the imminent new

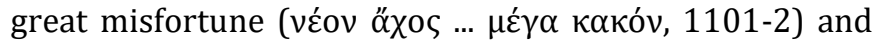
sees in advance the repeated series of blows of the ax with which Agamemnon will be killed. She sees what will be the boldness ( $\tau 0 \lambda \mu \tilde{\alpha} \iota)$ of Clitemnestra, the woman who kills the male, 1231.

Finally, destiny is truly accomplished. As the chorus once again emphasizes, every action is a consequence and, in turn, causes new action. Whoever decides to act and in doing so demonstrates to accept destiny inevitably suffers the consequences: "it is certain that, as long as Zeus is steadfast in his throne, he who acts

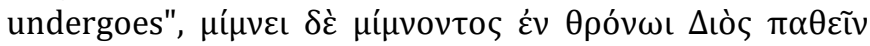

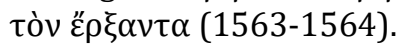

In a perspective of this kind, the original act - that is, the first risk decision - seems to fade into the distance.
Thus, on the one hand, in parallel with the story of Iphigenia, it also evokes that of Thyestes (brother of Atreus, the father of Agamemnon) and of his son Aegistus: and it is with the help of Aegistus that Clytemnestra makes his revenge. On the other hand - and Clytemnestra recalls this in the finale of the tragedy - "it was necessary

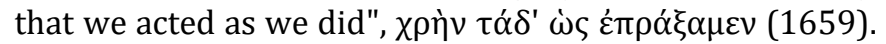
Under the banner of a destiny that everything seems to have determined, the life of the Greek man appears to be resolved in the rhythm of unavoidable decisions: a sort of relatively unpredictable moves and countermoves, of which however we could clearly retrace the causal chain. This chain, however, is only hinted at because it is continuously removed: only if fully illuminated could it lead back to the original and risky decision to act.

Something similar happens in the tragedy of Medea. Medea's decision to kill her rival (Jason's new wife) and her own children fits into an assigned destiny, and of this she is conscious as she is intimately aware that passion is stronger than reason. He had not accidentally answered the servant who had brought her the news of his rival's death: "Everything that happens is necessary, old man. The gods and I, in my madness, have hatched all this",

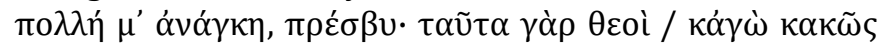

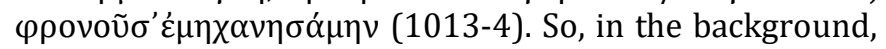
there is a necessity, but still deeper lies the possibility of risking to exist and to act within this necessity: to face the dangers which our life, and the decisions it implies, make inevitable.

In the Greek tragedy, we have 39 evidences of

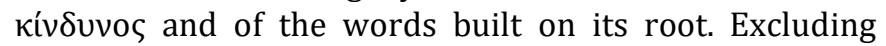
fragments in which the significance of meaning is not perspicuous, they are so distributed: Aeschylus $=4$, Sophocles $=3$, Euripides $=23^{20}$. Obviously, the privileged meaning is the most general one that is found in the expression: "to run risk". However, Sophocles already combines risk with thought (for example in Ant. 502) and, significantly, it makes Philoctetes say:

«You, who save me, take pity on me and look at how

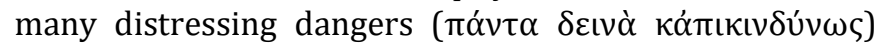
stand there waiting for mortals, and some will be bearable well, others badly. It is necessary that, as soon as one is out of suffering, he will look in the face what is frightening. If instead the life is good, we will have to watch over it so that it does not go wrong without us realizing it»,

\footnotetext{
${ }^{20}$ Aesch.,Th. 1028, 1048; Agam. 883; Choeph. 270. Soph., Ant..42; Phil. 502; Oed. Col. 564. Eurip. Cycl. 352, 654; Med. 248; Heraclid.148, 454, 504, 758; Hipp.1019; Andr.86; Hec.5, 244; Suppl. 572; Iphig.Taur. 90, 1001, 1022; Phoen.723, 1080, 1229, 1026; Or. 1159; Iphig.Aul. 17; Rhes.154, 588.
} 


\section{Philosophy International Journal}

Soph., Phil. 501-6.

The ability of "looking" is opposed to the worrisome and distressing living conditions, to pain and to what frightens man."Looking” means: to start a rational mechanism of "foresight", knowing that risks are by their nature inevitable and must be faced by man $(\eta \theta \lambda \eta \sigma \alpha$

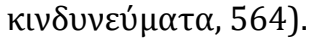

Later, with Euripides, the feeling of "having come to the threshold of a serious danger" (so, for example, in

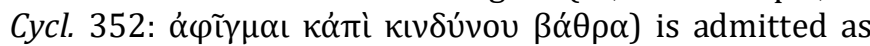
an eventuality and Odysseus, in Hec. 244, is perfectly aware of having slipped into a situation that he himself

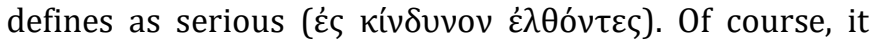
seems that the risk may, in a certain sense, be embracing or not embracing as one chooses, as when (in Heraclid. 503-4) the protagonist asks himself if he is or is not able

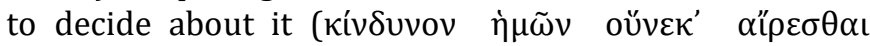

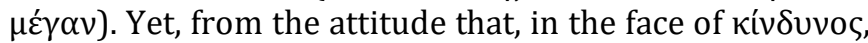
the individual subject holds, a life conduct can result where its threat appears mitigated: it is the case of

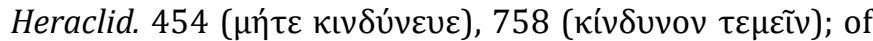

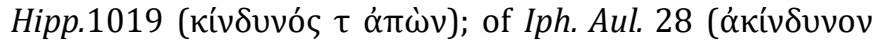
Bíov). It is not, however, that the problem can be solved definitively ${ }^{21}$ in this way - that is, focusing on an adequate life strategy - since the true risk (that is, the risk that lies behind the very possibility of acting and thinking) belongs to the ultimate background of man's existence and reflection on being. Because of this, we have the impression that, despite the reasoned approach to the different forms of danger, the underground tension remains. In the Phoenician Women (the tragedy focused on the story of Eteocles and Polynices), this element is immediately graspable: the deaths follow one after the other at a fast pace in the most complete incumbent of pathos. Creon's son, Menecaeus, throws himself from the walls of Thebes for the salvation of his fatherland; Eteocles and Polynices die by the hand of each other; Jocasta, their mother, kills herself on their bodies; all the chiefs of the Argives, who had fought against Thebes, die;

\footnotetext{
${ }^{21}$ This is also the case of Iphigenia and Orestes. Orestes declares himself

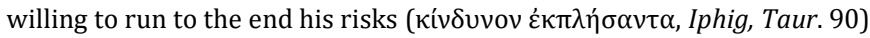
to take the statue of Artemis, as advised by the oracle. In this way he can take his sister Iphigenia with him, held in Tauris, by ship. It is a risk that

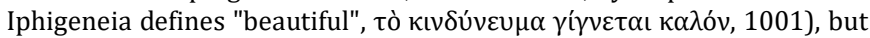
probably useless. Orestes insists: it is a risk to be attempted anyway

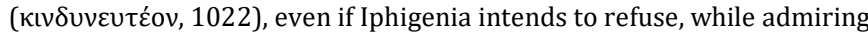

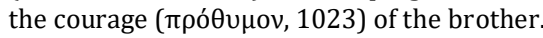

Polynices is left unburied while Oedipus is driven out of Thebes along with Antigone ${ }^{22}$.

One of the messengers seems to anticipate all this to Jocasta, suggesting to the hopeless mother the weight of the imminent destiny:

"If you still have some energy to oppose or words of wisdom

or some enchantment, come forward and hold your children

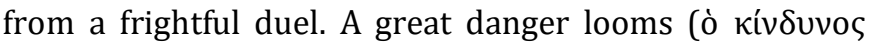
$\mu \varepsilon ́ \gamma \alpha \varsigma)$

and frightening is the prize of the race: you will have nothing but tears,

as private as you will be on this day of two children», Euripid., Phoen. 1259-63.

In short, here too, as more generally in the context of the Greek tragedy, tension develops and manifests itself between the games of destiny - which has failure and death as inevitable epilogues - and the courage or willingness to go towards it. The risk is evidently the condition in which the individual man arises when he decides to face his destiny ${ }^{23}$. And this condition is certainly with heroic implications: it allows the same man to look directly at his own existence and his own death, to understand the connection with nature in its most radical depth, to hypothesize decisions and actions for which guilt and responsibility will be attributed to him.

As we have seen, only at this point do phronêsis and technê come into play. They are the two most powerful means that the western man has available to (a) manage the situation of absolute uncertainty and risk in which the humana conditio has placed him; (b) definitively transform the insane risk into concrete "determined" danger; and (c) convert the ancient hero into the modern man, the master of technique and at the center of rational society. Ultimately, we are faced with the philosophical thought that is imposed in its definitive yet paradoxical form: the form for which the risk is not denied, but rather the inevitability is confirmed. Is it therefore correct to

\footnotetext{
${ }^{22}$ The theme of "transgression", implicit within the philosophical category of "risk", finds its maximum exemplification in Antigone's decision not to leave his brother unburied, in opposition to the law of the city of Thebes and the will of Creon.

${ }^{23}$ Certainly in the background lies destiny, and therefore the situation is summarized in formula: $\mathrm{B}=\mathrm{da}+\mathrm{i}$ «high-risk behavior», in which the subject plays with instability and puts its own security at risk. However, the hero decides something, and then becomes in some way the protagonist of a dangerous action. As we know, a «dangerous path» implies that the objective insecurity (i) of a $\mathrm{X}$ route (T) is made clear by the decision (d) of acting (a) by a certain subject S. Practically Ti $\subset$ Sdat.
} 
conclude by saying that risk has established itself as the authentic soul of the Western world? $[17,18]$.

\section{References}

1. Luhmann N (1991) Risk: A Sociological Theory (Communication and Social Order). De Gruyter, Berlin-New York.

2. Ernout A, Meillet A (1979) Etymological Dictionary of the Latin Language. History of words. Klincksieck, Paris.

3. Chantraine P (1983) Dictionnaire étymologique de la langue grecque. Histoire des mots. Klincksieck, Paris (or. ed. 1968).

4. Cortelazzo M, Zolli P (1979-1985) Dizionario etimologico della lingua italiana. Zanichelli, Bologna.

5. De Vaan M (2008) Etymological Dictionary of Latin and the Other Italic Languages. Brill, Leiden-Boston.

6. Beekes R, Beek L van (2010) Etymological Dictionary of Greek. 1-2 (Vol.), Leiden-Boston, Brill.

7. Maso S (2006) Fondements philosophiques du risque. L'Harmattan, Paris.

8. Heidegger M (1952) Holzwege. Klostermann, Frankfurt am Main.

9. Gehlen A (2004) Die Seele im technischen Zeitalter: Sozialpsychologische Probleme in der industriellen
Gesellschaft (1957-1971). In: Gesamtausgabe, von K.S. Rehberg, Klostermann, Frankfurta M.

10. Semerano G (1974) Le origini della cultura europea. 2nd (Vol)), 1: Dizionario Della lingua greca. Olschki, Firenze.

11. Natali C (2001) The Wisdom of Aristotle. State University of New York Press, Albany.

12. Maso S (2012) Val la pena rischiare? Qualche osservazione sulla categoria filosofica di «rischio» in Platone. "La Ricerca Folklorica" 66: 85-95.

13. Vernant JP, Vidal-Naquet $P$ (1981) Tragedy and myth in ancient Greece, Harvester Brighton (or. ed. 1972).

14. Destrée P (2011) Aristotle on Responsibility for One's Character. In: Pakaluk M, Pearson G (Eds.), Moral Psychology and Human Action in Aristotle. Oxford University Press, Oxford.

15. Dihle A (1982) The Theory of Will in Classical Antiquity. University of California Press, Berkeley Los Angeles - London.

16. Frede M (2011) A Free Will. Origins of the Notions in Ancient Thought. Berkeley - Los Angeles - London, University of California Press.

17. Beck U (1995) Risk Society: Towards a New Modernity. Blackwell, London (or. ed. 1986).

18. Beck U (2009) World at risk. Polity, Cambridge (or. ed. 2007). 